\title{
Economic feasibility for wastewater treatment system composed of wetlands for the wastewater reuse: a case study
}

Robson Muniz McMahon Waite ${ }^{1}$

Eduardo Gomes Salgado

Dirlane de Fátima do Carmo 3

\section{Abstract}

Water is an asset that is becoming scarce and its reuse is an alternative to preserve it. Social and environmental feasibility motivate the adoption of reuse, but the financial factor can be limited to its use. The objective of this study was to evaluate the economic and financial feasibility for the investment in a domestic wastewater treatment system in which the constructed wetlands could be used aiming at the reuse for irrigation. Instruments such as the minimum attractiveness rate, discounted payback, the internal rate of return and the profitability index were used. The treatment system composed of an equalization tank, a septic tank, horizontal subsurface flow constructed wetland, subsurface flow constructed wetland, and a maturation pond comprising $52 \mathrm{~m}^{2}$, demonstrating that it is able to meet the criteria required for reuse. The organic load affluent to the system was projected to $220 \mathrm{mg} \mathrm{L}^{-1}$ at a flow rate of $600 \mathrm{~L} \mathrm{day}^{-1}$ of sewage, obtaining removal efficiency above $98 \%$ for all parameters, except nitrogen and phosphorus. In the analysis of economic and financial feasibility, it was found that the internal rate of return found for the cash flow considered was $98 \%$ and the profitability index according to the present value was 3.28. It was found that the total employed would be recovered in up to two years. With the use of the system, $180 \mathrm{~m}^{3}$ of water would be saved annually, reducing the pressure on the public supply system, in addition to the sewage treatment and the scenic beauty provided by wetlands. Therefore, the system is not limited only to economic gains, but also to social and environmental gains.

Keywords: Reutilization. Sewage. Economic viability.

\section{Introduction}

In recent years, water scarcity in Brazil has been constantly presented in the media. The granting of rights to use water resources and charging for that use, instruments established by the National Water Resources Policy in 1997, led many industries and commercial establishments to a new model of water management, based on strategies for the conservation of this resource, based mainly on rationalization and reuse (AQUINO; 2015; WEBER; CYBIS; BEAL, 2010; DEMAJOROVIC; CARUSO; JACOBI, 2015).

Thus, for industries, reusing their effluents after appropriate treatment as far as possible is a more attractive option, with lower installation and operating costs than those associated with capturing and water treatment from springs or purchasing water offered by sanitation companies, both for drinking

1 Universidade Federal Fluminense, Departamento de Engenharia Agrícola e Meio Ambiente, Campus da Praia Vermelha, Niterói/RJ. robsonwaite@hotmail.com.

2 Universidade Federal de Alfenas. Professor associado. egsalgado@yahoo.com.br.

3 Universidade Federal Fluminense. Professora Associada. dirlanefc@id.uff.br. 
systems and for water reuse systems (FIESP, 2005). Water reuse programs in the industry can reduce the consumption of this resource by up to $80 \%$ (RIBEIRO, 2012). However, according to Ribeiro (2012), the growth of reuse in Brazil is still very small concerning its potential.

In Brazil, there is still no federal legislation on reuse. The non-potable water reuse is allowed as a rationalization practice, and the guidelines for that are established in Resolution n. 54 of the National Council of Water Resources (CNRH, 2005), presenting, among other advantages, the reduction in the discharge of pollutants in receiving bodies and the conservation of water resources for public supply and other uses that demand higher quality. However, for the planned direct reuse, presented in Resolution n. 54 (CNRH, 2005), there is a need to invest in treatment, whether through biological, physical-chemical, or mixed systems. However, processes that use little or no energy are rare; they do not require the use of chemical; it has a low cost of implementation, operation, and maintenance. Therefore, the system of constructed wetlands (CW) should be noted, which is able to mix all these characteristics and can become a natural solution for most of the difficulties found.

Modern constructed wetlands are systems designed to emphasize and improve specific characteristics of natural water purification and waste management systems, with the decomposition and capture of nutrients and contaminants (RUSSI et al., 2013). There are, therefore, different configurations: to the flow (surface or subsurface flow); vegetation (floating, emergent or submerged plants); flow (horizontal or vertical) (WALLACE; KNIGHT, 2006).

The treatment efficiency of pollutants varies from one model to another. According to Kayombo et al. (2004), subsurface flow constructed wetlands are appropriate systems for the treatment of primary effluents, since there is no contact between the effluent and the atmosphere, whereas surface flow constructed wetlands are indicated for the secondary and tertiary effluent treatment and to provide habitat for living beings. The pollutant removal mechanisms found in wetlands are diverse: sedimentation, filtration, precipitation, and chemical adsorption, in addition to microbial interactions and complexation (MARQUES, 1999).

Wetlands do not usually meet the standard of effluents discharge required by law, such as the one presented in Resolution n. 430 of the National Environment Council (CONAMA, 2011). In general, constructed wetlands have been used as after treatment or polishing systems, which is considered a tertiary treatment, and their application to wastewater with a high organic load is still limited (CHIEMCHAISRI et al., 2009). The greater interest in the use of wetlands in recent decades is due to the relatively low cost of construction and management compared to other alternatives (JOHANSSON et al., 2004). As wetlands are constructed using local labor and material, it is not possible to present estimates of universal costs, applicable to all treatment systems (WALLACE; KNIGHT, 2006), but it is possible to make a study of the economic and financial viability that will allow, through projections and figures, indicate the potential return on investment.

Although Brazil has enormous potential for the use of $\mathrm{CW}$, since it is located in the tropics without snow in winter in most of its territory, little research is done on the use of CW in the country when compared to other kinds of treatment. In the National Basic Sanitation Plan, for example, when presenting the investment needs for sewage treatment units considering the base years of 2014, 2018, 2023 and 2033, the combination of technologies involving upstream flow anaerobic reactors, percolator biological filters, stabilization ponds and activated sludge system (PLANSAB, 2013), as they are commonly used in the country. Thus, the sizing methods for the construction of wetlands used in Brazil are, for the most part, modeled for the temperate region, as the methods of Reed et al. (1995), Kadlec and Knight (1996) and Platzer (1998). 
The environmental and aesthetic advantages of using CW for wastewater treatment are highlighted in several studies, but the economic viability assessments of their use are still incipient.

According to Padoveze (2005), the investment in a project must be evaluated concerning its return. Thus, according to economic criteria, projects with greater acceptance will have a positive net present value (NPV) or equal zero, or will have the highest internal rate of return, at the company's discretion. Additionally, according to Salles (2004), the financial analysis of projects is usually based on estimates for the future project cash flow, obtained from forecasts for several variables. The cash flow initial analysis is made through representative values for the considered variables, allowing the calculation of deterministic financial indicators. Also, according to Salles (2004), in order to obtain sufficient creditors' financing to guarantee the cost of preparing a project, to convince them to invest, it is necessary to prove the economic and the enterprise financial viability and its ability to guarantee credit for the payment of the financing debt.

The application of the economic and financial feasibility study, therefore, can assist in the decision to implement a project that presents environmental and social feasibility. Costa et al (2014), for example, demonstrated the feasibility of implementing a chemical waste treatment and recovery laboratory in a public agency with the application of economic and financial feasibility study.

Thus, the present study aims to evaluate the economic and financial feasibility of using wetlands with the aid of a maturation pond and a septic tank for the domestic wastewater treatment for reuse. Instruments such as the minimum attractiveness rate were used; discounted payback; the internal rate of return and the profitability index for investing in a wastewater treatment system where $\mathrm{CW}$ could be used for water treatment and reuse.

\section{Material and methods}

For the development of this study, Eletrobrás Electric Energy Research Center (CEPEL) was chosen as a case study, located in the university city, Ilha do Fundão, Rio de Janeiro. CEPEL was created in 1974 , on the initiative of Eletrobrás. The selection of CEPEL had as criteria its importance in the scenario of pioneering sustainable energy, its representativeness since it is the largest electric energy center in South America and its contribution to the promotion of sustainable development (CEPEL, 2015).

A dimension for part of the wastewater generated aiming at reuse was made. The wastewate generated at Fundão Unit of Cepel are not classified as industrial, because despite having laboratories, the wastewater generated by them is stored in approved plastic drums and destined for a licensed treatment company. To carry out this study, the average values of domestic wastewater were used, as indicated by Metcalf and Edy (2003), as shown in Table 1:

Table 1 - Characterization of the estimated effluent for dimensioning the CEPEL treatment system

\begin{tabular}{lcc}
\hline \multicolumn{1}{c}{ Parameters } & Units & Average values \\
\hline TSS & $\mathrm{mg.}^{-1}$ & 220.0 \\
Turbidity & UNT & 160.0 \\
BOD & $\mathrm{mg} \mathrm{L}^{-1}$ & 220.0 \\
COD & $\mathrm{mg} \mathrm{L}^{-1}$ & 500.0 \\
Total nitrogen & $\mathrm{mg} \mathrm{L}^{-1}$ & 40.0 \\
Total phosphorus & $\mathrm{g} \mathrm{L}^{-1}$ & 8.0 \\
Total coliforms (Ct) & Org 100 $\mathrm{mL}^{-1}$ & $10^{9}$ \\
\hline
\end{tabular}

Source: Elaborated by the authors (2015). 
In the treatment system proposal, the objective was to reuse it for irrigation, because it would require less treatment and it would be more economical, besides not requiring major reforms in Cepel's hydro-sanitary installation. Considering the estimated consumption of $15 \mathrm{~m}^{3} \mathrm{month}^{-1}$, the utilization of water reuse would represent savings of $180 \mathrm{~m}^{3}$ year ${ }^{1}$. There was, therefore, a need for an adequate minimum quality that would not be achieved only with wetlands. Thus, the system was composed of biological reactors to maintain a low operating cost, being as follows: an equalization tank (EQT), a septic tank (ST), horizontal subsurface flow constructed wetland (HSFCW) and a surface flow constructed wetlands (SFCW) and finally a maturation pond. The equalization tank was dimensioned according to Embrapa (2015) and the septic tank according to the Brazilian standard of the Brazilian Association of Technical Standards - ABNT NBR 7229/93 (ABNT, 1993). The CWs were dimensioned using the equations model by Reed et al. (1995) for both types of CW. Additionally, the maturation pond was dimensioned using the method proposed by Von Sperling (2006). The design parameters adopted are shown in Table 2 for a daily sewage affluent volume of $600 \mathrm{~L}_{\text {day }}{ }^{-1}$ :

Table 2 - Basic parameters used for the reactor design

\begin{tabular}{|c|c|c|}
\hline Reactors & Holding time (days) & Affluent volumetric organic load $\left(\mathrm{mg} \mathrm{L}^{-1}\right)$ \\
\hline$\overline{E Q T}$ & 1 & 220.00 \\
\hline ST & 1 & 220.00 \\
\hline HSFCW & 2 & 88.00 \\
\hline SFCW & 11 & 14.33 \\
\hline Maturation pond & 20 & 0.00 \\
\hline
\end{tabular}

Source: Elaborated by the authors (2015).

Figure 1 shows the components of the system used in the present study:

Figure 1 - System designed to treat CEPEL wastewater.

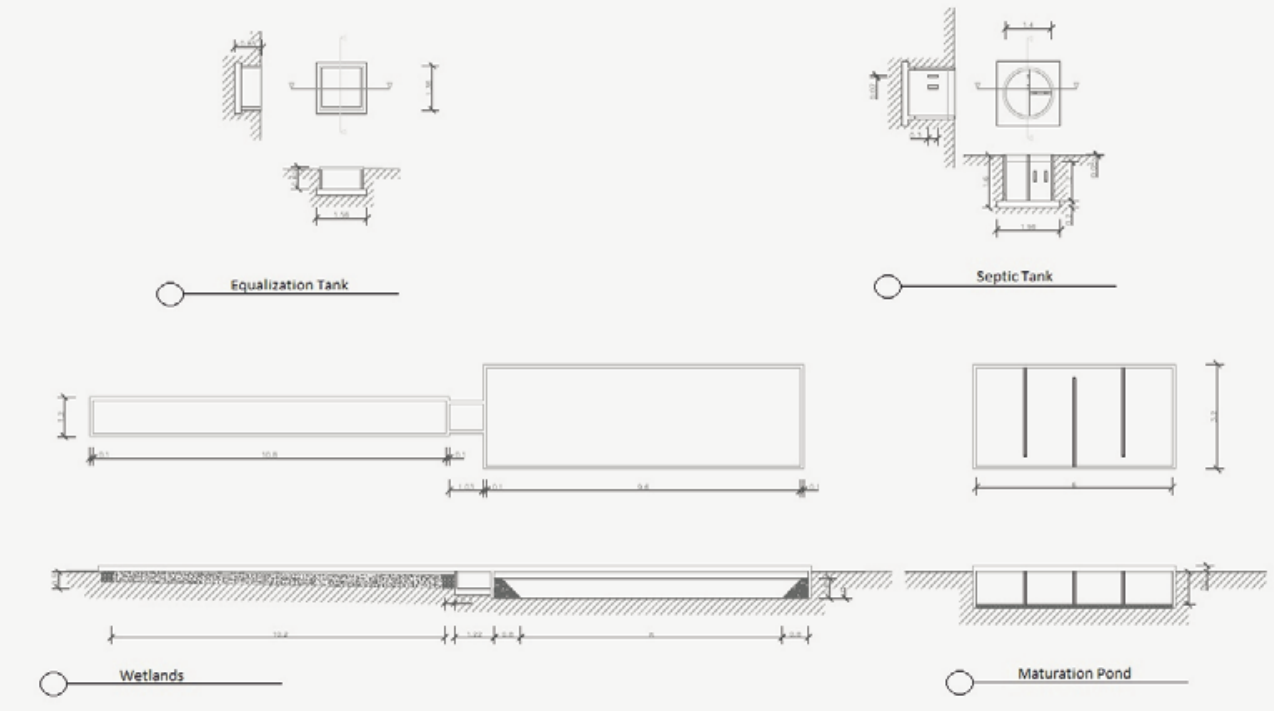

Source: Elaborated by the authors (2015). 
As this study aims to evaluate the technical and economic feasibility of a system proposed for reuse without major changes in the company's hydraulic structure, it was dimensioned to meet the consumption of irrigation in the gardens $\left(0.6 \mathrm{~m}^{3} \mathrm{day}^{-1}\right)$ and to fit in class II recycled water of the Brazilian Association of Technical Standards - NBR 13.696 (ABTN, 1997).

The $52 \mathrm{~m}^{2}$ treatment system was budgeted with the Volare software for budgeting, planning, and control of works. Volare works with data from the National System of Costs Survey and Indexes of Construction (SINAPI) that allows users to prepare budgets with compositions accepted by the main public agencies in Brazil.

For the economic and financial feasibility study, the minimum attractiveness rate (MAR) was used, which is a rate that varies according to the policy practiced by each company, which can be defined as the discount rate, or the MAR most appropriate for investment decisions, such as the rate of the cost of capital (SCHROEDER, 2005). In the present study, a value for the MAR was stipulated according to the annual savings rate in Brazil in 2015 (6\% p.a.), as it is the most stable and secure application in the financial market. $4.5 \%$ of risk (referring to the inflation rate in Brazil in 2015) was added because it is a system with considerable risk. Therefore, MAR equals to $10.5 \%$ a.a.

The discounted payback was another instrument used. Discounted payback is the exact time required for the company to recover the initial investment, from the cash inflows, using the attractiveness rate previously defined, in order to consider the value of money over time.

And, finally, the internal rate of return (IRR) and the profitability index (PI) were used. The internal rate of return is the calculation of the discount rate that would have a given cash flow to equal its net present value to zero, that is, the rate of return on the investment made, while the profitability index is the relative measure between the present value of the cash flows received and the initial investment. The IRR can be calculated according to the following expression by Rêgo et al. (2013):

$$
I R R=\sum_{n=1}^{N} \frac{C t}{(1+R o R)^{n}}=0
$$

At which:

$\mathrm{Ct}=$ Cash Flow

$\mathrm{N}=$ Holding Period

RoR $=$ Rate of return

$\mathrm{n}=$ Each Period

The method, or discounted cash flow method (DCF), according to Rêgo et al. (2013), aims to understand the cash flow of a project. Therefore, if the NPV is positive the project is accepted, that is, we have the investment recovered and remunerated at a rate that exceeds the MAR. The NPV is given by the following equation by Rêgo et al. (2013):

$$
N P V=-I+\sum_{T=1}^{N} \frac{N C t}{(1+r)^{t}}+\frac{R V}{(1+r)^{n}}
$$

at which:

I = initial investment

$\mathrm{NCt}=$ net cash flow on date " $\mathrm{t}$ "

$\mathrm{N}=$ duration of the project

$\mathrm{n}=$ number of project periods

$\mathrm{t}=$ each period

$r=$ capital cost defined by the company

$\mathrm{RV}=$ residual value of the project at the end of the analysis period 
The profitability index method considers the ratio between the present value of the cash flow and the initial value of the investment. It can be calculated using the following formula by Rêgo et al. (2013):

$$
P I=\frac{P V}{l_{0}}
$$

at which:

$\mathrm{PI}=$ profitability index

$\mathrm{PV}=$ present value

Io $=$ Initial investment of the project

The project will be recommended whenever the $\mathrm{PI}$ is greater than one (1). If the $\mathrm{PI}$ is equal to one, it means that the amount invested will be paid only, and finally, the project will prove unfeasible for PI values below one.

\section{Results and discussion}

In assessing the application of reuse at CEPEL's facilities, it was found that the main alternatives would be for washing cars, flushing toilets, and irrigating gardens. However, based on data provided by CEPEL, gardens irrigation would not require major renovation in the hydro-sanitary installation and would imply a reduction in the consumption of $15 \mathrm{~m}^{3}$ month-1 of water supply, which would result in savings of $180 \mathrm{~m}^{3}$ year $^{-1}$.

The system was structured in such a way that the equalization tank sized according to EMBRAPA (2015) with $0.6 \mathrm{~m}^{3}$ of useful volume, functioned as an inlet flow regulator, while the septic tank, sized according to NBR 7229 (ABNT, 1993), of cylindrical shape with three chambers of $1.8 \mathrm{~m}^{3}$ of useful volume, had the main function of reducing the amount of total suspended solids (TSS) of the horizontal subsurface flow constructed wetland (HSFCW). It should be noted that clogging the discharge zone is a common problem in HSFCW, and it is expected that with the septic tank that will not happen.

The septic tank theoretical efficiency was established from literature data collected by Ávila (2005). Thus, an efficiency of $80 \%$ ( $176 \mathrm{mg} \mathrm{L}^{-1}$ ) for the removal of total soluble solids was estimated; $74 \%$ (118.40 unT) to reduce turbidity; $60 \%$ for the removal of BOD and COD (respectively, 132.00 and $\left.300.00 \mathrm{~m} \mathrm{~L}^{-1}\right) ; 12 \%\left(4.8 \mathrm{mg} \mathrm{L}^{-1}\right)$ removal for total nitrogen; $6.70 \%\left(0.536 \mathrm{mg} \mathrm{L}^{-1}\right)$ efficiency in removing total phosphorous; and $25.30 \%\left(2.53 \times(10) \wedge 7\right.$ Tc Org.100 $\left.\mathrm{ml}^{-1}\right)$ efficiency for the removal of total coliforms.

The HSFCW preceding the SFCW was also positioned that the effluent would only come into contact with the atmosphere in the third treatment stage, in order to avoid the bad smell. CWs were dimensioned using the equations model by Reed et al. (1995) for both types of CW. The model assumes that the chemical transformations are irreversible and occur at a homogeneous rate proportional to the concentration of particles, that is, with first-order kinetic reactions. According to the model described by Reed et al. (1995), it was considered that the reactions would occur with non-zero inlet flow and equal to the outflow, with the particle retention time equal to the hydraulic detention time, that is, with a piston-type hydraulic flow model. This approach, that CWs function as piston flow reactors with first-order reactions, ignores the influence of factors such as precipitation, evapotranspiration, and non-ideal flow patterns (CHAGAS, 2011). 
The surface area was estimated according to Troesch et al. (2012), which recommends values of $2 \mathrm{~m}^{2}$ per taxpayer. The flow of $0.6 \mathrm{~m}^{3}$ day-1 used for the project according to NBR 7229 (ABNT, 1993) refers to 12 contributors, considering that for this type of enterprise the contribution per person is 50 liters. Soon $24 \mathrm{~m}^{2}$ would be needed, which would be divided between HSFCW and SFCW. However, due to the desired quality since the proposal was effluent reuse, an area of $10 \mathrm{~m}^{2}$ was adopted for HSFCW and the area of SFCW was increased to $24 \mathrm{~m}^{2}$ in order to achieve the planned efficiency.

The macrophytes expected to be used in HSFCW and SFCW were, respectively, cattail (Typha sp), and water hyacinth (Eichornia crassipes), with depths according to the needs of the roots, that is, the depth of $0.30 \mathrm{~m}$ (BRAZIL et al., 2007) and that of the $0.6 \mathrm{~m}$ water hyacinth (RIBEIRO, 1986).

The dimensioning method from Reed et al. (1995) does not have equations to calculate the reduction in chemical oxygen demand (COD), total nitrogen (NT), and turbidity, thus, the efficiency of these items was also estimated from data from the literature. Jorge (2013) indicates that for an SFCW that uses water hyacinth as vegetation there is an efficiency of $95 \%$ to reduce turbidity, $98.50 \%$ to reduce COD, and 6\% reduction to NT (JORGE, 2013). Table 2 summarizes the theoretical efficiency of each stage of the proposed system.

To finish the system, a maturation pond with $18 \mathrm{~m}^{3}$ was dimensioned for polishing the effluents, especially for removing fecal coliforms.

It can be seen from Table 2 that the proposed system, due to the quality of the effluent generated, can meet the criteria required for classification in class II of water reuse of NBR 13,696 (ABTN, 1997). The removal efficiency values are above $98 \%$ for all parameters, except for nitrogen and total phosphorus, which is beneficial, since the reuse of the intended effluent is in the garden's irrigation and both are nutritional elements for vegetation. Therefore, it is a technically feasible system to meet the goal of reuse.

Table 2 - Efficiency of the system by weighting each part of it:

\begin{tabular}{lcccccc}
\hline \multirow{2}{*}{ Parameters } & $\begin{array}{c}\text { Cepel } \\
\text { Effluent }\end{array}$ & Ts & SFCW & SFCW & Lm & $\begin{array}{c}\text { Cepel } \\
\text { Effluent }\end{array}$ \\
\cline { 2 - 7 } & Entrada & \multicolumn{7}{c}{ Remoção } & Saída \\
\hline TSS (mg L-1) & 220 & $176^{*}$ & $38.17^{1}$ & $5.13^{1}$ & 0 & 0.69 \\
Turbidity (unT) & 160 & $118.4^{*}$ & 0,00 & $39.52^{*}$ & 0 & 2.08 \\
BOD (mg L-1) & 220 & $132^{*}$ & $73.67^{*}$ & $14.25^{1}$ & 0 & 0.07 \\
COD (mg L-1) & 500 & $300^{*}$ & 0.00 & $197^{*}$ & 0 & 3.00 \\
Nt (mg L-1) & 40 & $4.8^{*}$ & 0.00 & $21.12^{*}$ & 0 & 14.08 \\
Ft (mg L-1) & 8 & $0.536^{*}$ & $2.72^{1}$ & $3.15^{1}$ & 0 & 1.59 \\
Tc org 100ml-1 & $1 \times 10^{8}$ & $2.53 \times 10^{7 *}$ & $5.27 \times 10^{7 *}$ & $2.5 \times 10^{7 *}$ & $1.5 \times 10^{6}{ }_{* *}$ & 300.41 \\
\hline
\end{tabular}

* estimated values; ${ }^{1}$ theoretical values

Source: Elaborated by the authors (2015).

The basic project budget for the proposed treatment system was prepared with the necessary services separated into the following groups: earthmoving; waterproofing; pre-treatment; masonry and additional services. 
For the earthmoving, it would be necessary to excavate $75.04 \mathrm{~m}^{3}$, from which only $7.07 \mathrm{~m}^{3}$ would return to the ditch, the rest $\left(67.97 \mathrm{~m}^{3}\right)$ should be removed by trucks.

The waterproofing service would require $86.40 \mathrm{~m}^{2}$ of $2.5 \mathrm{~mm}$ thick high-density polyethylene geomembrane to ensure the integrity of any existing water table and $53.69 \mathrm{~m}^{2}$ of waterproofing paint would still be applied to the entire masonry.

The pretreatment system would require $39.76 \mathrm{~m}^{2}$ of wooden forms since there is no bespoke system, prefabricated parts are not found on the market, and $6.43 \mathrm{~m}^{3}$ of concrete would also be needed for its construction.

The CWs were designed with flower pots delimiting them in order to contain any extrapolation of effluent, as well as to differentiate the CW from the other gardens. Thus, it was accounted for $52.56 \mathrm{~m}^{2}$ of masonry.

The additional services would include the services of the required hydrosanitary system and other small services within the execution of the project. The final amount including all social charges, security requirements for workers, and other fees were estimated at $\$ 10,006.92$, with an estimated project construction time of 30 days (one month).

Based on the $\$ 10,006.92$ value of the basic project budget, and considering a $10 \%$ annual increase in the first year expenses $(\$ 2,766.57)$ in the cash flow, an inflation-based increase rate in 2015 , and also considering that the gains $(\$ 12,861.24)$ were not changed, since it was assumed that the organization size is constant, the study of the economic and financial viability demonstrated that the period of return on investment is only two years, as it can be seen in Table 3 discounted payback, considering a minimum attractiveness rate (MAR) of $10.5 \%$ per year.

The Internal Rate of Return (IRR) found for the considered cash flow was 98\%, approximately ten times higher than the value of the (MAR) $(98 \%>10.5 \%)$. Thus, it turns out that the project is economically viable.

The profitability index found (PI), considering the present value, was 3.28. According to Rêgo et al. (2013), the PI>1 value means that the investment will be recovered, remunerated at least at the required rate and there will also be an increase in wealth. The feasibility of the project is determined by the value of IRR $>$ MAR.

Table 3 - Discounted Payback

\begin{tabular}{cccc}
\hline Time & $\begin{array}{c}\text { Cash flow } \\
\text { (dollar) }\end{array}$ & Present value (dollar) & Aggregate value (dollar) \\
\hline 0 & $-10,006.92$ & $-10,006.92$ & $-10,006.92$ \\
1 & $10,094.66$ & $9,135.44$ & -871.48 \\
2 & $9,818.01$ & $8,040.79$ & $7,169.31$ \\
3 & $9,513.68$ & $7,051.18$ & $14,220.49$ \\
4 & $9,178.93$ & $6,156.63$ & $20,377.12$ \\
5 & $8,810.70$ & $5,348.09$ & $25,725.21$ \\
6 & $8,405.64$ & $4,617.40$ & $30,342.61$ \\
7 & $7,960.09$ & $3,957.14$ & $34,299.75$ \\
8 & $7,469.97$ & $3,360.63$ & $37,660.38$ \\
9 & $6,930.84$ & $2,821.80$ & $40,482.18$ \\
10 & $6,337.81$ & $2,335.16$ & $42,817.34$ \\
\hline
\end{tabular}

Source: Elaborated by the authors (2015). 
Therefore, the project economic feasibility study showed that the total investment will be recovered in up to two years and that the project's viability is guaranteed with a profitability index four times higher than the amount needed to recover. An increase in wealth and an internal rate of return ten times higher than the minimum rate of attractiveness are also expected.

To compare this study with others, it was necessary to make currency conversions. Thus, the value of euro considered was 1.10 dollars (pricing on August 11th, 2015, at 07:32 PM) and 3.47 reais (pricing on August 11 th, 2015 at 08:18 PM).

Due to the scarcity of economic evaluations of projects using CW in Brazil, we used studies carried out outside the country in order to compare their results with the data obtained in the present study. Two projects were found with a feasibility study for comparison, one of them comprises a standard septic tank and an SFCW with two $25 \mathrm{~m}^{2}$ beds, designed by Hoddinott (2006) for a house with 5 contributors without reusing the effluent in the state of Ohio (United States), with an area of approximately $50 \mathrm{~m}^{2}$. The second was a project by Albold (2011), referring to a decentralized station constructed in Vidrare, Bulgaria that comprised an $18 \mathrm{~m}^{3}$ septic tank with $3 \mathrm{~m}^{2}$ in the area and two SFCW beds with $133 \mathrm{~m}^{2}$ dimensioned using the German National Guide for sustainable treatment options. Albod's 2011 system aimed at serving a community with 95 contributors, with an area of approximately $269 \mathrm{~m}^{2}$. Both systems include primary and secondary treatment, with the final destination being discharged into rivers.

Table 4 summarizes the results obtained in the present study and those used for comparison. It can be seen that the price per contributor at this study (CEPEL) is not very different from the prices of Albod's 2011 project, but it is almost half the value per contributor of Hoddinott's 2006 project.

Table 4 - Cost of the projects used for comparison with those of the present study

\begin{tabular}{lccc}
\hline Project & Albold (2011) & Hoddinott (2006) & CEPEL \\
\hline Number of Contributors & 95 & 5 & 12 \\
CW used area & $266 \mathrm{~m}^{2}$ & $50 \mathrm{~m}^{2}$ & $52 \mathrm{~m}^{2}$ \\
Septic Tank Volume & $18 \mathrm{~m}^{3}$ & & $2.4 \mathrm{~m}^{3 *}$ \\
\hline Project Construction & & Cost & \\
Services & & ud & $\$ 2,606.90$ \\
\hline Excavation and Plumbing & $\$ 13,264.69$ & ud & $\$ 1,432.83$ \\
Pre-Treatment (concrete) & $\$ 6,632.34$ & ud & $\$ 1,035.02$ \\
Soil waterproofing & $\$ 6,632.34$ & ud & $\$ 1,553.76$ \\
Substrate in Constructed & $\$ 7,737.74$ & & ud \\
Wetland & $\$ 15,475.47$ & $\$ 8,000.00$ & $\$ 10,006.97$ \\
Hydrosanitary & $\$ 49,742.58$ & $\$ 1,600.00$ & $\$ 833.91$ \\
installations & $\$ 523.61$ & & \\
Total & & & \\
Cost per Contributor & &
\end{tabular}

ud - unreported data; * equalization tank + septic tank

Source: Elaborated by the authors (2015).

The projects of Albod (2011) and CEPEL allow a more complete comparison for having more detailed information. The excavation cost of the Albod's 2011 project was estimated at $\$ 49.87$ per square meter, roughly the same value as CEPEL's project of $\$ 50.13$ per square meter. The 
pretreatment of Albod's project was estimated at $\$ 368.46$ per cubic meter, a slightly lower value than the CEPEL project value of $\$ 597.01$, but the pretreatment of the CEPEL project counts also with an equalization tank system. The soil waterproofing of the Albod's 2011 project was budgeted at $\$ 24.93$ per square meter, while the CEPEL project was at 19.90 . The cost of the substrate in Albod's project was $\$ 29.09$ per square meter, which is very close to the CEPEL project value of $\$$ 29.88. Hydro-sanitary installations were not compared because the system developed for Albod's 2011 project is not known in detail.

The comparison between the projects reinforces that the system proposed by the present study has budgetary data very close to the real ones, and that the disagreements between the studies can be attributed to the differences between the labor laws, by the year of the projects execution.

\section{Conclusions}

The treatment system designed for the wastewater reuse at CEPEL, consisting of a septic tank followed by two wetlands and a ripening pond, is technically and economically viable.

With the use of the system, $180 \mathrm{~m}^{3}$ of water would be saved annually, which could be reallocated, reducing the pressure on the public water supply system and consequently on the environmental systems, in addition to the treatment of the sewage generated and the scenic beauty provided by the wetlands. Therefore, the system is not limited only to economic gains, but also to social and environmental gains.

With the achieved results in carrying out this work, as well as the knowledge acquired in the development of the study, it is possible to suggest the following studies to be developed: Evaluate in other public establishments the feasibility of using constructed wetlands (CW) system for wastewater polishing; evaluate the feasibility of using the treated effluent reuse in constructed wetlands (CW) for storage and use in crops; compare the economic, financial and technical study of wetlands with other sustainable methodologies used for wastewater treatment.

One of the limitations found was the impossibility of comparing the efficiency system of the projects of Albod (2011), Hoddinott (2006), and CEPEL, since in the first two projects the objective was not the reuse and, because of that, they had a lower frame value.

\section{Viabilidade econômica de sistema de tratamento de esgoto composto com wetlands visando ao reúso de efluente: estudo de caso}

\section{Resumo}

A água é um bem que vem se tornando escasso e o reúso é uma alternativa para preservá-la. A viabilidade social e a ambiental motivam a adoção do reúso, mas o fator financeiro pode ser limitante ao seu emprego. 0 objetivo deste trabalho foi avaliar a viabilidade econômica financeira para 0 investimento em um sistema de tratamento de efluente doméstico em que as wetlands construídas pudessem ser empregadas visando ao reúso para irrigação. Foram utilizados instrumentos como a taxa mínima de atratividade; o payback descontado; a taxa interna de retorno e o índice de lucratividade. O sistema de tratamento, composto por um tanque de equalização, um tanque séptico, uma wetland construída de fluxo subsuperficial horizontal, uma wetland construída de fluxo superficial e uma lagoa de maturação, compreendeu 52,0 $\mathrm{m}^{2}$, demonstrando ser capaz 
de atender aos critérios exigidos para reúso. A carga orgânica afluente ao sistema foi projetada para 220,0 $\mathrm{mgL}^{-1}$ em uma vazão de 600,0 L dia-1 de esgoto, obtendo-se eficiência de remoção superior a 98\% para todos os parâmetros, exceto nitrogênio e fósforo. Na análise de viabilidade econômica e financeira (EVEF), verificou-se que a taxa interna de retorno encontrada para o fluxo de caixa considerado foi de $98,0 \%$ e o índice de lucratividade acatando o valor presente foi de 3,28. Verificou-se que o total investido seria recuperado em até dois anos. Com a utilização do sistema seriam poupados anualmente $180,0 \mathrm{~m}^{3}$ de água, reduzindo a pressão sobre o sistema de abastecimento público, além do tratamento do esgoto e da beleza cênica proporcionados pelas wetlands. Portanto, o sistema não se limita apenas a ganhos econômicos, mas também a ganhos sociais e ambientais.

Palavras-chave: EVEF. Reutilização. Água residuária.

\section{References}

ALBOLD, A.; WENDLAND, C.; MIHAYLOYA, B.; ERGUNSEL, A.; GALT, H. Constructed wetlands: sustainable wastewater treatment for rural and peri-urban communities in Bulgaria, case study. Bulgaria: Women in europe for a common future, 2011. 21 p.

AQUINO, V. Reúso, solução para escassez x legislação e regulamentação deficitária. Revista Tae, fevereiro de 2015. Disponível em: <http: http://www.revistatae.com.br/8761-noticias> Acesso em 23. Jul. 2015.

ASSOCIAÇÃO BRASILEIRA DE NORMAS TÉCNICAS - ABNT. NBR 7229: Construção e operação de sistemas de tanques sépticos. Rio de janeiro, 1993. $15 \mathrm{p}$.

ASSOCIAÇÃO BRASILEIRA DE NORMAS TÉCNICAS - ABNT. NBR 13696: Tanques sépticos unidades de tratamento complementar e disposição final de efluentes líquidos - projeto, construção e operação. Rio de janeiro, 1997. 60 p.

ÁVILA, R. O. Avaliação do desempenho de sistemas tanque séptico - filtro anaeróbio com diferentes tipos de meio suporte. 2005, 166 p. Tese. Universidade Federal do Rio de Janeiro, Rio de Janeiro, 2005.

BCB - BANCO CENTRAL DO BRAIL. Cotações e boletins. Disponível em: <https://www4.bcb.gov. br/pec/taxas/port/ptaxnpesq.asp?frame=1>. Acesso em: 11 ago. 2015.

BRASIL, M. S.; MATOS, A. T.; SOARES, A. A. Plantio e desempenho fenológico da taboa (thypha sp.) utilizada no tratamento de esgoto doméstico em sistema alagado construído. Revista Engenharia Sanitária e Ambiental, v. 12, n. 3, p. 266-272, jul/set 2007.

CEPEL, 2015. Disponível em: http://www.cepel.br/. Acesso em:10 jul. 2015.

CHAGAS, R. C.; MATOS, A. T.; CECON, P. R.; LO MONACO, P. A. V.; FRANÇA, L. G. F. Cinética de remoção de matéria orgânica em sistemas alagados construídos cultivados com lírio amarelo. Revista brasileira de engenharia agrícola e ambiental. Campina Grande, v. 15, n. 11, p. 1186-1192, 2011. 
CHANG, D.; MA, Z. Wastewater reclamation and reuse in Beijing: Influence factors and policy implications. Desalination, 297, p. 72-78, 2012.

CHIEMCHAISRI, C; CHIEMCHAISRI, W.; JUNSOD, J.; THREEDEACH, S.; WICRANARACHCHI, P.N. Leachate treatment and greenhouse gas emission in subsurface horizontal flow constructed wetland. Bioresource Technology, 100, p. 3808-3814, 2009.

CONSELHO NACIONAL DE RECURSOS HÍDRICOS - CNRH. Resolução n. 54. Estabelece modalidades, diretrizes e critérios gerais para a prática de reúso direto não potável de água. 28 de novembro de 2005.

COSTA, L. T.; SALGADO, E. G.; CARMO, D. F.; GUERRA, M.; EVANGELISTA, M.; SILVEIRA, K. (2014). Laboratório de tratamento e recuperação de resíduos químicos: alternativa para resíduos industriais do sul de Minas Gerais. Revista Brasileira de Desenvolvimento Regional, v. 2, n. 2, p. 225-243, 2015.

DEMAJOROVIC, J.; CARUSO, C.; JACOBI, P. R. Cobrança do uso da água e comportamento dos usuários industriais na bacia hidrográfica do Piracicaba, Capivari e Jundiaí. Rev. Adm. Pública, v. 49, n. 5, p. 1193-1214, set./out. 2015.

EMPRESA BRASILEIRA DE PESQUISA AGROPECUÁRIA - EMBRAPA. Sistema de tratamento e compostagem. Sistema de tratamento de dejetos suínos: inventário tecnológico. 2015. Disponível em: <http://www.cnpsa.embrapa.br/invtec/35.html>. Acesso em:10 jul. 2015.

FEDERAÇÃO DAS INDÚSTRIAS DO ESTADO DE SÃO PAULO. Manual de conservação e reúso de água em edificações. São Paulo: Gráfica, 2005. 152 p.

HODDINOTT, B. C. Horizontal subsurface flow constructed wetlands for on-site wastewater treatment. Dissertação de mestrado, Wight State University, Ohio, 2006. 84 p.

JOHANSSON, A. E.; GUSTAVSSON, A. M.; QUIST, M. G. O; SVENSSON, B. H. Methane emissions from a constructed wetland treating wastewater-seasonal and spatial distribution and dependence on edaphic factors. Water Research. v. 38, p. 3960-3970, 2004.

JORGE, C. M. B. P. Tratamento das águas residuais dos dejetos de suínos com aguapé, um estudo de caso no campus Nilo Peçanha. In: CONGRESSO NACIONAL DE EXCELÊNCIA EM GESTÃO, IX, 2013, Rio de Janeiro. Anais... Rio de Janeiro: 2013, 15 p. Disponível em: http://www.excelenciaemgestao. org/portals/2/documents/cneg9/anais/t13_2013_0016.pdf Acesso em: 5 de jul. 2015.

KAYOMBO, S. MBWETTE, T. S. A.; KATIMA, J. H. Y.; LADEGAARD, N.; JRGENSEN, S. E. Waste stabilization ponds and constructed wetlands design manual. University of dar es salaam, Copenhagen, Denmark, 2004, 59 p.

MARQUES, D. M. Terras úmidas construídas de fluxo Sub-superficial. In: CAMPOS, J.R. (coord.). Tratamento de esgotos sanitários por processo anaeróbio e disposição controlada no solo. Prosab, 1999. P. 409-435. 
METCALF, L.; EDDY, H. P. Wastewater Engineering Treatment Disposal Reuse.4. ed. New York, McGraw - Hill Book, 1815 p. 2003

PADOVEZE, C. L. Planejamento orçamentário: texto e exercícios. São Paulo: Pioneira/ Thomson Learning, 2005.

PLANSAB - Plano Nacional de Saneamento Básico. Brasília: dezembro, 2013. 173 p.

PLATZER, C.; HOFFMANN, H.; CARDIA, W. O wetland como componente de ecosan- experiências com o uso e dimensionamento no clima subtropical. In: INTERNATIONAL CONFERENCE ON SUSTAINABLE SANITATION: FOOD AND WATER SECURITY FOR LATIN AMERICA, Fortaleza, 2007. Proceedings... Fortaleza: ECOSANLAC/IWA, 2007.

REED, S. C.; CRITES, R. W.; MIDDLEBROOKS, E. J. Natural Systems for Waste Management and Treatment - 2. ed. McGraw Hill, New York, 1995.p. 173-284.

REGO, R. B.; PAULO, G. P.; SPRITZER, I. M. P. A.; ZOTES, L. P. Viabilidade econômico-financeira de projetos. FGV, 4. ed. 2013. 172 p.

RIBEIRO, M. C. M. Mercado de reúso de água no brasil: é possível assegurar um crescimento sem a definição de um arcabouço normativo e legal? Revista Dae, 2012, p. 4-9.

RIBEIRO, M. D.; KAWAI, H.; TINEL, P. R.; ROSSETTO, R. Experimento piloto da lagoa aguapé para tratamento de esgoto bruto. Revista Dae, v. 46, 1986.

RUSSI, D.; BRINK, P. T.; FARMER, A.; BADURA, T.; COATES, D.; FÖRSTER, J.; KUMAR, R.; DAVIDSON, N. The Economics of Ecosystems and Biodiversity (TEEB) for Water and Wetlands. 2013. 84 p.

SALLES, A. C. N. Metodologias de análise de risco para avaliação financeira de projetos de geração eólica. 2004, 93 p. Tese de doutorado. Programas de Pós-Graduação de Engenharia da Universidade Federal do Rio de Janeiro, Rio de Janeiro, 2004.

SCHROEDER, J. T.; SCHROEDER, I.; COSTA, R. P.; SHINODA, C. O custo de capital como taxa mínima de atratividade na avaliação de projetos de investimento. Revista Gestão Industrial. v. 1, n. 2, 2005.

TROESCH, S.; ESSER, D. Constructed wetlands for the treatment of raw wastewater: the French experience, Sustainable Sanitation Practice, p. 9-15, 2012.

VOLARE, 205. Disponível em: <http://pinisistemas.pini.com.br>. Acesso em: 15 maio 2015.

VON SPERLING, M. Lagoas de estabilização. 2. ed. 2. reimpressão. Belo horizonte. Departamento de engenharia sanitária e ambiental, Universidade Federal de Minas Gerais. 196 p. 2006.

WALLACE, S. D.; KNIGHT, R. L. Small-scale constructed wetland treatment systems: feasibility, design criteria and O\&M requirements. 2006. WERF - Water Environment Research Foundation. 304 p. 
WEBER, C. C.; CYBIS, L. F.; BEAL, L. L. Conservação da água aplicada a uma indústria de papelão ondulado. Eng Sanit Ambient, v. 15, n. 3, 2010, p. 291-300.

Received in: August 7, 2019

Accepted in: November 8, 2019 